\title{
A quick study on SRL profiles of online learning participants during the anticipation of the spread of COVID-19
}

\author{
Dwi Sulisworo $^{1}$, Nur Fatimah ${ }^{2}$, Septi Shinta Sunaryati ${ }^{3}$, Sanidi ${ }^{4}$ \\ ${ }^{1}$ Department of Physics Education, Universitas Ahmad Dahlan, Indonesia \\ ${ }^{2}$ Department of English Education, Universitas Ahmad Dahlan, Indonesia \\ ${ }^{3}$ SMK Marsudi Luhur I, Indonesia \\ ${ }^{4}$ SMA Negeri I Krangkeng, Indonesia
}

\begin{tabular}{l}
\hline \hline Article Info \\
\hline Article history: \\
Received Apr 4, 2020 \\
Revised Jun 12, 2020 \\
Accepted Jul 18, 2020
\end{tabular}

Keywords:

Active learning

COVID-19

Learning outcomes

Online learning

Self-regulated learning

\begin{abstract}
The spread of the COVID-19 coronavirus occurs in all countries. This pandemic incident has been taken seriously by various sectors including in the world of education. This research is a quantitative descriptive study to explain the Self-Regulated Learning (SRL) profile of Indonesian students in online learning which is carried out in COVID-19 emergencies. The research commenced three days after the establishment of the WHO COVID-19 pandemic. The respondents were taken by accident sampling at several schools implementing online learning after the designation of this mode by the Indonesian Ministry of Education and Culture on March 15, 2020. The schools comprised general high schools and vocational schools. The data were collected via Google Form filled out by 10th to 12th-grade students. The instrument used was a questionnaire with a scale of 1 to 5 (from absolutely disagree to absolutely agree) consisting of planning, monitoring, controlling, and reflecting aspects. There were two analytical techniques used i.e., descriptive statistics and ANOVA. The results of this study indicate that students in Indonesia still need assistance and mentoring from teachers to improve SRL. Several mentoring strategies can be applied to manage active learning. The teachers should explicitly include the process of mentoring, strengthening the students' SRL. Teachers need to be aware that online learning is not only to master certain subject matters but also to strengthen SRL.
\end{abstract}

This is an open access article under the CC BY-SA license.

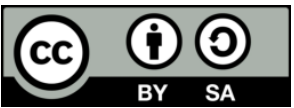

\section{Corresponding Author:}

Dwi Sulisworo,

Department of Physics Education,

Universitas Ahmad Dahlan,

Jalan Prof. Dr. Supomo, Janturan, Yogyakarta, 55164, Indonesia.

Email: sulisworo@gmail.com

\section{INTRODUCTION}

The spread of the COVID-19 coronavirus occurs in all countries. This pandemic incident has been taken seriously by various sectors including in the world of education. Numerous nations have decided to choose to close schools, and colleges. The emergency takes shape, the predicament policymakers are looking between shutting schools and keeping them open $[1,2]$. Indonesia, as a country with a substantial population, has issued various policies concerning learning. All schools in Indonesia are encouraged to implement distance learning by utilizing information technology. There are many public responses regarding this policy, and in general, all parties agree. The main obstacle to the implementation of this learning mode is the availability of facilities and infrastructure in several areas. To support this policy, several large 
telecommunication industry providers in Indonesia have prepared a free bandwidth quota of up to 30 GB per person to join online learning freely. There is an assumption that in this social distancing setting, education is best delivered virtually as a transition situation $[3,4]$.

Policies in this emergency positively affect people's behavior. All educator and policymkers agree that classes may be suspended without stopping learning [5]. Educators and students hasten to be able to adjust to the new interaction behavior of online learning. Various applications begin to be learned quickly and are used in learning, such as Moodle, Edmodo, Google Classroom, Schoology, Zoom, and others. There is high optimism among educators in the implementation of this learning. The school management must ensure in this emergency student learning still sustain [6]. This learning certainly also has implications for students' readiness to engage in learning. Many research results show that online learning fails [7-9] because there is no social presence in learning. Students become burdened with academic assignments that sometimes exceed the burden when learning in class. This condition is because educators do not measure the learning load or capacity in an emergency. On the other hand, it is necessary to see whether or not the students have the ability to manage themselves.

The ability to manage oneself is an essential factor in achieving learning goals including in the COVID-19 mitigation [10]. One of the concepts on an overview of the ability to manage onself is the concept of self-regulated learning (SRL). It can be used to measure how a person is planning goals, managing activities and behavior, controlling him/herself to stay in accordance with the objectives and also reflecting to make improvements in order to achieve goals $[11,12]$. Students who have high ability in SRL will tend to be more successful in accomplishing the learning goals [11-13]. In online learning, where learning control is higher in students, SRL becomes an important issue to study. This research is a quantitative descriptive study to explain the SRL profile of Indonesian students in online learning is carried out in COVID-19 emergencies.

\section{LITERATURE REVIEW}

Self-regulated learning (SRL) is an essential factor in the learning process. SRL is determined by three important factors, they are aspects of self, behavior and environment. The interaction of these three factors will form individuals who can bring up certain self-behaviors leading to good performance [14]. Students who can manage themselves in learning well, they will be responsible for their learning activities. They define goals and problems to bear, develop a standard level of perfection in achieving the goals, and evaluate the best way to accomplish them. They not only apply these behaviors in classroom learning, but they can also implement them to online learning [13]. SRL students can be identified through their active participation in directing metacognitive processes, motivations and behavior while they are learning. From some literature studies about SRL, this concept refers to the deliberate and strategic adaptation of the learning process to change cognitive, motivational, and behavioral outcomes $[14,15]$. In the context of education and learning, self-regulation refers to the proactive application of self-directive processes, cognitive behavior, and emotions to achieve goals, to learn skills, and to manage emotional reactions $[15,16]$. This process is a process where students are able to direct themselves while learning, able to plan, organize, direct themselves and conduct self-evaluations at various levels during the process of information gathering $[14,16]$. In online learning, where student focus becomes important, SRL becomes a factor that needs special attention by educators to ensure the success of the learning process $[17,18]$.

Simply, the process of self-regulation is defined as the activities of individuals in planning, monitoring the plans, making changes to stay on track, and reflecting on what works and what can be improved in the future [19-21]. One of the instruments used in SRL measurement is the Independent Regulatory Formative Questionnaire. This questionnaire measures the perception of students' proficiency levels in four crucial components of self-regulation: planning and articulating what the students want to achieve; immediately monitoring progress and disturbances related to the student goals; controlling changes by implementing specific strategies when things do not go as planned; and reflecting what works and what the students can do better in the future [15].

Self-regulation in online learning is the ability to reveal and monitor one's thoughts, feelings, and behaviors to achieve learning goals by using online applications and the features available. Self-regulation of learning is essential, so students have independence in learning to use information from the internet [22-24]. Self-regulation is the ability of a person to maintain or change his or her personality to follow moral values in society [25] using their competence [26] in the cyberspace. The aspects of SRL are metacognition, motivation, and affirmative action. Healthy self-regulation stages can encourage the achievement of expected learning goals [27, 28]. SRL can also be in the form of cognitive regulation, motivational regulation, behavioral regulation, and emotional regulation [15, 29] when individuals interact with other students and teachers [30]. It is inseparable from the social support provided to them. Considering this concept, 
the teacher's ability to provide an online environment that is socially similar to real conditions is a crucial factor in the success of online learning that supports students' SRL.

In addition to the fact of SRL as a psychological concept, it is also a strategy in cognitive learning [16]. There is a very significant positive correlation between academic achievement and the use of self-regulation strategies in learning [17, 21, 22, 29]. The research findings show that although a student has high ability, his academic achievement will not be optimal if he or she is not able to regulate him/herself in learning. In many recommendations it has been suggested that SRL be used to improve academic achievement [20, 29]. Thus, teachers who explicitly emphasize the improvement of SRL when managing learning will be able to assist students in improving learning achievement. The role of teachers becomes important as students' social support in developing their SRL [27, 28].

The social support plays an important role for students in the online learning process and it can affect their learning achievement [31,32]. Such support refers to the pleasure they felt, appreciation for caring, or helping the students accept other people or groups [33]. It can be seen as a social fact of support actually occurring or provided by others to individuals (perceived support) and as individual cognition it refers to perceptions of received support [34]. In another angle of view, social support is an interpersonal relationship where individuals provide assistance to other individuals and the assistance is in the form of participation, emancipation, motivation, availabilty of information, and appreciation or assessment of individuals. The social support in online learning can be obtained from teachers and peers. Good interaction between teachers and students in addition to increasing social support in increasing SLR, it will also be able to foster social presense in online learning that will affect learning comfort $[35,36]$. This support can be seen in the choice of words, emoticons, language expressions, speed, and accuracy when responding to one's posts [37, 38].

\section{RESEARCH METHOD}

\subsection{Research settings}

The research commenced on March 16, 2020, three days after the establishment of the WHO COVID-19 pandemic. The respondents were taken by accident sampling at several schools implementing online learning after the designation of this mode by the Indonesian Ministry of Education and Culture on March 15, 2020. The schools consisted of general high schools (SMA-Sekolah Menengah Atas) and vocational schools (SMK-Sekolah Menengah Kejuruan). The data were collected via Google Form (from 16 to March 19, 2020) filled out by 10th to 12th-grade students through teachers carrying out online learning and willing to voluntarily get involved for this data collection.

Due to the limited time and bureaucracy during the online learning adjustment period, in this study there were only 15 schools out of 13 regencies in Indonesia that could participate (8 SMK and 7 SMA). All of these schools have never carried out online learning, therefore in this mitigation period they needed to make various adjustments both teachers and students. There were 81 students who filled out the questionnaire in this quick time (56 students from vocational schools, 25 students from general high schools, as the research samples).

\subsection{Instruments}

The instrument used was a questionnaire (see Table 1) with a scale of 1 to 5 (from absolutely disagree to absolutely agree). The overall self-regulation questionnaire was found to be highly reliable (22 items; $\alpha=.896)$ as tested previously. The planning subscale consisted of 5 items $(\alpha=.632)$, the monitoring subscale consisted of 6 items $(\alpha=.704)$, the controlling subscale consisted of 6 items $(\alpha=.744)$, and the reflecting subscale consisted of 5 items $(\alpha=.682)$. Table 1 shows the matrix for each factor and item of SRL.

There were two analytical techniques used i.e., descriptive statistics and MANOVA. First, descriptive data (average and standard deviation) were used for each factor in comparing the profiles among schools. Then, MANOVA on each SLR factor was used to see the effects of students' grades. This analysis was applied to see the differences in the effect of School Type on SRL factors. 
Table 1. Questionnaire matrix

\begin{tabular}{|c|c|}
\hline & Item statements \\
\hline \multirow{4}{*}{$\begin{array}{l}\text { Factor 1: Planning } \\
\quad \text { (5 items) }\end{array}$} & I plan out projects that I want to complete. \\
\hline & If an important test is coming up, I create a study plan. \\
\hline & Before I do something fun, I consider all the things that I need to get done. \\
\hline & I can usually estimate how much time my homework will take to complete. \\
\hline \multirow{7}{*}{$\begin{array}{l}\text { Factor } 2 \text { : Monitoring } \\
\text { (6 items) }\end{array}$} & I have trouble making plans to help me reach my goals. (-) \\
\hline & I keep track of how my projects are going. \\
\hline & I know when I'm behind on a project. \\
\hline & I track my progress in reaching my goals. \\
\hline & 9. I know what my grades are at any given time. \\
\hline & 10. Daily, I identify things I need to get done and track what gets done. \\
\hline & 11. I have trouble remembering all the things I need to accomplish. (-) \\
\hline \multirow{5}{*}{$\begin{array}{c}\text { Factor } 3 \text { : Controlling } \\
\text { (6 items) }\end{array}$} & 12. I do what it takes to get my homework done on time. \\
\hline & 13. I make choices to help me succeed, even when they aren't the most fun right now. \\
\hline & 14. As soon as I see things aren't going right, I want to do something about it. \\
\hline & 15. I keep trying as many different possibilities as necessary to succeed. \\
\hline & 16. I have difficulty maintaining my focus on projects that take a long time to complete. (-) \\
\hline \multirow{6}{*}{$\begin{array}{l}\text { Factor 4: Reflecting } \\
\text { (5 items) }\end{array}$} & 17. When I get behind on my work, I often give up. (-) \\
\hline & 18. I think about how well I'm doing on my assignments. \\
\hline & 19. I feel a sense of accomplishment when I get everything done on time. \\
\hline & 20. I think about how well I've done in the past when I set new goals. \\
\hline & 21. When I fail at something, I try to learn from my mistake. \\
\hline & 22. I keep making the same mistake over and over again. (-) \\
\hline
\end{tabular}

\section{RESULTS AND DISCUSSION}

\subsection{Result}

The data obtained through the Google Form filled out by students participating in online learning reveal SRL profiles in each aspect. They are presented in Table 2. Table 2 shows that overall each aspect of SRL has a relatively good score (more than 3.0), but only in the Reflecting aspect, it scores above 4. With a standard deviation between .51 to .77 , the data depict that the students' SRL on online learning is relatively even. How the means differences in all aspects of SRL are illustrated in Figure 1 to Figure 4.

Figure 1 to Figure 4 show that vocational students tend to be higher in all aspects of SRL except in the Reflecting aspect. However, further analysis using Multivariate Tests (Wilks' Lambda) reveals no significant differences between vocational high schools and general high schools $(F=1.982$, $p$-value $=0.05)$. This result means that SRL of vocational high school students is no different from that of the general high school students.

Tests of between-subjects effects were carried out to see more detailed differences among SRL aspects. The results of this test are presented in Table 3. From this table, there are no significant differences (p-valie $=0.05$ ) between schools in all aspects (Sig. $=0.060$ for Planning; Sig. $=0.864$ for Monitoring; Sig. $=$ 0.220 for Controlling and Sig. $=0.454$ for Reflecting). The results from Table 3 implies that vocational and general schools have the same SRL on each factor. It also means that teachers may apply a generic strategy to improve the SRL for both school types.

Table 2. Descriptive statistics

\begin{tabular}{ccccc}
\hline & School Type & Mean & Std. Deviation & $\mathrm{N}$ \\
\hline \multirow{3}{*}{ Planning } & Vocational High School & 3.6643 & .52585 & 56 \\
& General High School & 3.3840 & .77011 & 25 \\
& Total & 3.5778 & .62048 & 81 \\
\multirow{4}{*}{ Monitoring } & Vocational High School & 3.4315 & .61609 & 56 \\
& General High School & 3.4067 & .56536 & 25 \\
& Total & 3.4239 & .59748 & 81 \\
& Vocational High School & 3.7440 & .50848 & 56 \\
Reflecting & General High School & 3.5667 & .76073 & 25 \\
& Total & 3.6893 & .59847 & 81 \\
& Vocational High School & 3.9786 & .60143 & 56 \\
& General High School & 4.0880 & .61395 & 25 \\
& Total & 4.0123 & .60361 & 81 \\
\hline
\end{tabular}

Int. J. Eval. \& Res. Educ. Vol. 9, No. 3, September 2020: 723 - 730 


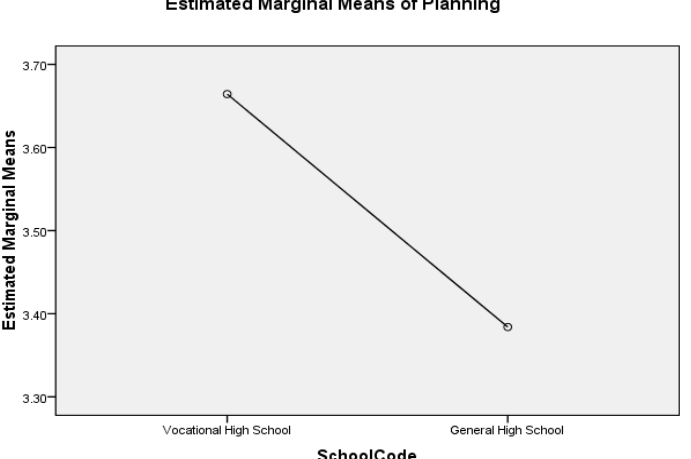

Figure 1. Planning aspect

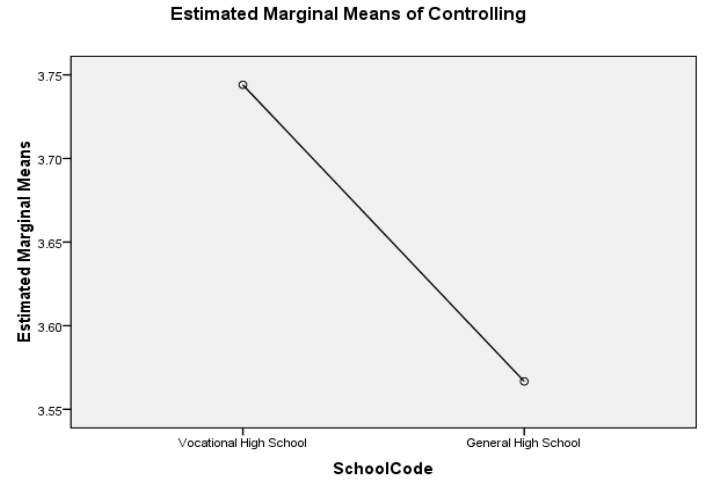

Figure 3. Controlling aspect

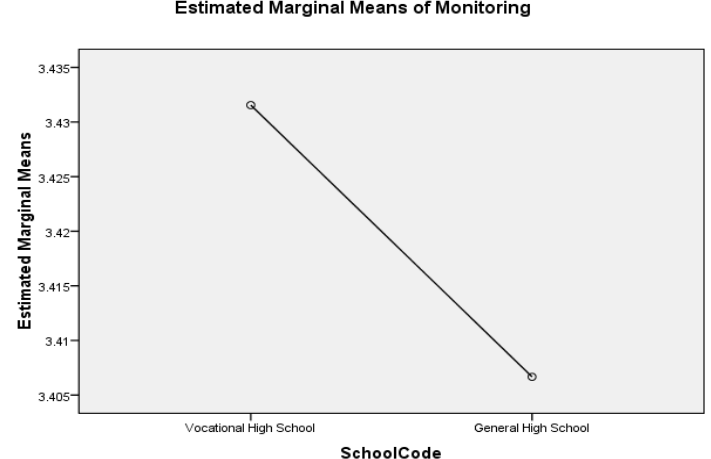

Figure 2. Monitoring aspect

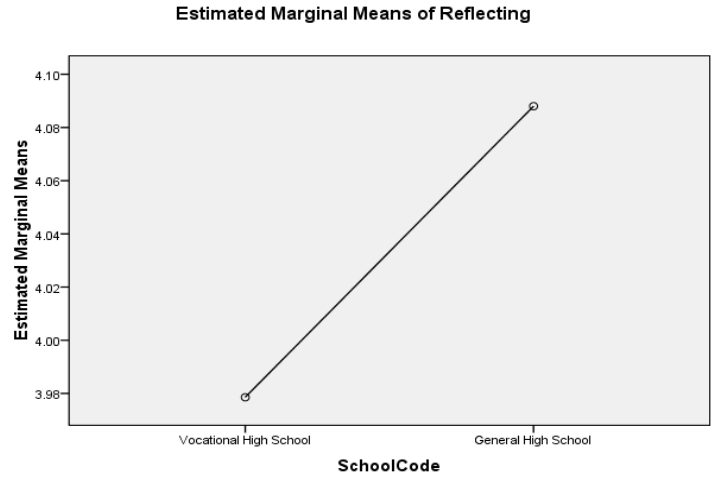

Figure 4. Reflecting aspect

Table 3. Tests of between-subjects effects

\begin{tabular}{|c|c|c|c|c|c|c|}
\hline Source & Dependent Variable & Type III Sum of Squares & $\mathrm{df}$ & Mean Square & $\mathrm{F}$ & Sig. \\
\hline & Planning & 1.358 & 1 & 1.358 & 3.643 & .060 \\
\hline Corrected & Monitoring & .011 & 1 & .011 & .030 & .864 \\
\hline \multirow[t]{3}{*}{ Model } & Controlling & .544 & 1 & .544 & 1.528 & .220 \\
\hline & Reflecting & .207 & 1 & .207 & .565 & .454 \\
\hline & Planning & 858.638 & 1 & 858.638 & 2303.919 & .000 \\
\hline \multirow{4}{*}{ Intercept } & Monitoring & 808.218 & 1 & 808.218 & 2236.588 & .000 \\
\hline & Controlling & 923.767 & 1 & 923.767 & 2596.225 & .000 \\
\hline & Reflecting & 1124.659 & 1 & 1124.659 & 3070.006 & .000 \\
\hline & Planning & 1.358 & 1 & 1.358 & 3.643 & .060 \\
\hline \multirow{4}{*}{ SchoolCode } & Monitoring & .011 & 1 & .011 & .030 & .864 \\
\hline & Controlling & .544 & 1 & .544 & 1.528 & .220 \\
\hline & Reflecting & .207 & 1 & .207 & .565 & .454 \\
\hline & Planning & 29.442 & 79 & .373 & & \\
\hline \multirow{4}{*}{ Error } & Monitoring & 28.548 & 79 & .361 & & \\
\hline & Controlling & 28.109 & 79 & .356 & & \\
\hline & Reflecting & 28.941 & 79 & .366 & & \\
\hline & Planning & 30.800 & 80 & & & \\
\hline Corrected & Monitoring & 28.558 & 80 & & & \\
\hline \multirow[t]{2}{*}{ Total } & Controlling & 28.653 & 80 & & & \\
\hline & Reflecting & 29.148 & 80 & & & \\
\hline
\end{tabular}

\subsection{Discussion}

SRL, both in online learning and classroom-based learning, which is offline, refers to the ability to understand and control the learning environment. The ability of SRL includes the attempts to set goals (Planning), self-monitoring (Monitoring), self-instruction (Controlling), and self-reinforcement (Reflecting) [14, 39, 40]. SRL cannot be used for measuring academic performance. The reason is that SRL is more related to mental abilities or skills in achieving a goal that can be related to various things. SRL can be developed through a development process that arises from guided practice and feedback so that

A quick study on SRL profiles of online learning participants during the anticipation of ... (Dwi Sulisworo) 
the behaviors will change mental abilities with new skills and habits. In online (virtual) learning, students who have an excellent SRL will be better able to deal with the development of a learning environment that is different from their real world. With a good SRL, students can find, select, use any information from the internet to solve problems or achieve learning goals.

From this research results, as explained in the result section, it appears that high school students in Indonesia still need assistance to improve their SRL. Some findings in online learning during COVID-19 mitigation show that the teachers tend to give higher academic assignments (academics presence) to each subject matter or lesson. This finding will have an impact on the vast number of tasks to accomplish. With such inadequate SRL skills, the students can fail in this online learning. Students who have low SRL tend to be less responsible for the learning process $[14,16]$. Some new challenges in online learning make them give up more quickly and they do not try to achieve the learning goals.

In certain cases when students need to search for information via the internet, they tend not to do so to strengthen learning performance. Such students depend on the content provided by the teacher. In addition, the lack of SRL also makes students not motivated in learning; this was seen in their intensity in interacting online on the learning platform used. Motivation is an important part of SRL [11, 14, 15]. Low motivation also results in low learning performance. In addition, students with low SRL have low cognitive management skills. This situation makes students less able to manage the learning process, the strategies chosen in completing assignments, and in directing their activities to achieve learning goals [20, 29].

The ability of SRL will determine learning outcomes, teachers and school policymakers need to consider including the process of assisting in strengthening the SRL in the learning design prepared for online learning. It is essential to determine the strategies that encourage students to apply when dealing with virtual information. The activities to encourage better SRL include explaining the benefits and importance of SRL, teaching SRL strategies explicitly, and helping identify when and how to use SRL when dealing with online information for their learning $[12,15]$. Through these activities, it can be expected that there will be an improvement of SRL among high school students in Indonesia. Indeed, suddenly applied digital technology due to COVID-19's mitigation will affect students' daily activities and the achievement of their skills $[1,4,5]$.

Based on experiences in joining and conducting e-learning courses, there were at least two critical points enabling learning to happen. Setting and informing explicitly the learning objectives helped the learners aware of what to achieve by the end of the learning process. Also, asking the learners to write their feedback was of significance. Through it, they can self assess what they learned and achieved, describe how students felt, inform what challenge or even difficulty they got during the learning session. Through the feedback, the students could self assess what they have learned and achieved. It described what the students have felt, informed what challenge or even difficulty they have got during the learning session.

At the same time, the teacher could also get the feedback to evaluate the program and measured the success or failure in facilitating the learners in achieving the objectives. The way the teachers organized online learning could have profound effects on the ability of students to become autonomous learners. The crucial factors in online learning were not only delivering the subject matters or problem-solving but also explicitly teaching students how to learn. When joining an e-course, the teacher provided the students with "happy online learning" before the e-learning sessions. The role of the teacher in online learning was providing a learning environment that allowed the students to be more capable in self-management by using the various facilities available in the online learning platform. The teacher gave a trigger so that the students could support one another both with motivating words (i.e. those that were not underestimating), positive emoticons, supporting feedback on an idea from their mates [18, 24]. This conducive atmosphere was one form of social support in online learning [31, 38]. Students felt satisfied in online learning when the level of 'attendance' of teachers and students in learning was quite high.

Furthermore, that was very helpful to make the student aware that teacher communicated with a human teacher through a machine i.e., computer. Furthermore, strategies in the form of "happy online learning" were very helpful as the introduction to interact during online learning sessions. In the strategies of "happy online learning" the students were provided with details of how to communicate with a human teacher and mates through a machine i.e. computer. Such strategies stimulated proper behaviours along the students' learning journey virtually. Since various online rapports also occured between the teacher and students and among students, problems in online learning emerged. This dynamic was managed by determining a particular approach to the problem. One of the techniques was conducting both synchronous and asynchronous dialogues to produce and evaluate shared ideas. The dialogues were about how the learning process or problem-solving in online interactions. The lesson learned is that when choosing a learning strategy, explain the reason why the approach is to be used in online learning. Students learning new materials generally do not know which strategy is best to apply. They may lose interest or motivation if they are not trained and encouraged [14]. Online communication to introduce and to make them understand that 
idea is essential. When the techniques the students learned and understood are useful in a particular activity, motivation and self-satisfaction will increase [41].

\section{CONCLUSION}

Online learning carried out suddenly due to the anticipation of the spread (mitigation) of COVID-19 has provided many new opportunities even though it is with several obstacles encountered. Students' SRL abilities also determine success in online learning. The results of this study indicate that students in Indonesia still need assistance and mentoring from teachers to improve SRL. Several mentoring strategies can be applied to manage active learning. In the learning design, the teachers should explicitly include the process of mentoring, strengthening the students' SRL. Teachers need to be aware that online learning is not only to master certain subject matters but also to strengthen SRL. This awareness is leading to a long-term impact on students' learning behaviors.

\section{ACKNOWLEDGEMENTS}

The authors would like to thank to Ministry of Education and Culture Republic of Indonesia that funded this research under National Competitive Research Grant for the Year 2020.

\section{REFERENCES}

[1] Burgess S. and Sievertsen HH., "Schools, skills, and learning: The impact of COVID-19 on education," VoxEu. org, 2020. [Onlline]. Available: https://voxeu.org/article/impact-covid-19-education

[2] Viner RM, et al., "School closure and management practices during coronavirus outbreaks including COVID-19: A rapid systematic review," The Lancet Child \& Adolescent Health, vol. 4, no. 5, pp. 397-404, 2020.

[3] Schwartz AM, et al., "Managing resident workforce and education during the COVID-19 pandemic: Evolving strategies and lessons learned," JBJS Open Access, vol. 5, no. 2, p. e0045 2020.

[4] Basilaia G. and Kvavadze D., "Transition to online education in schools during a SARS-CoV-2 Coronavirus (COVID-19) pandemic in Georgia," Pedagogical Research, vol. 5, no. 4, Article No: em0060, 2020.

[5] Zhang W, Wang Y, Yang L, Wang C., "Suspending classes without stopping learning: China's education emergency management policy in the COVID-19 outbreak," J. Risk Financial Manag, vol. 13, no. 3, p. 55, 2020

[6] Semin FK., "Competencies of principals in ensuring sustainable education: Teachers' views," International Journal of Evaluation and Research in Education, vol. 18, no. 2, pp. 201-12, 2019.

[7] Alhomod S. and Shafi MM., "Success factors of e-learning projects: A technical perspective," Turkish Online Journal of Educational Technology-TOJET, vol. 12, no. 2, pp. 247-53, 2013.

[8] Mawere M. and van Stam G., "eLearning in an African place: How 'alien'elearning models are failing many in Africa," International conference on social implications of computers in developing countries, pp. 421-432, 2019.

[9] Lam P, Lee J, Chan M, and Tong A., "Use of information technology in school-related activities and its perceived benefits among teachers and students in secondary and primary schools in Hong Kong," International Conference on e-Learning, pp. 228-235, 2012.

[10] Sintema EJ., "Effect of COVID-19 on the Performance of grade 12 students: Implications for stem education," Eurasia Journal oF Mathematics, Science and Technology Education, vol. 16, no. 7, pp. 1-6, 2020.

[11] Chiu YL, Liang JC, and Tsai CC., "Internet-specific epistemic beliefs and self-regulated learning in online academic information searching," Metacognition and learning, vol. 8, no. 3, pp. 235-60, 2013.

[12] Mooij T., "Education and ICT-based self-regulation in learning: Theory, design and implementation," Education and Information Technologies, vol. 14, no.1, p. 3, 2009.

[13] Dunn KE. and Rakes GC., "Exploring online graduate students' responses to online self-regulation training," Journal of Interactive Online Learning, vol. 13, no. 4, pp. 1-21, 2015.

[14] Zimmerman BJ. and Schunk DH., "Self-regulated learning and performance: An introduction and an overview," Handbook of self-regulation of learning and performance, pp. 15-26, 2011.

[15] Persico D. and Steffens K., Self-regulated learning in technology enhanced learning environments, in Carneiro, R., Lefrere, P., Steffens, K., Underwood, J. (Eds.), “Technology Enhanced Learning,” pp. 115-126, 2017.

[16] Inan F, Yukselturk E, Kurucay M, and Flores R., "The impact of self-regulation strategies on student success and satisfaction in an online course," International Journal on E-learning, vol. 16, no. 1, pp. 23-32, 2017.

[17] Pei-Ching C, Min-Ning Y, and Fang-Chung C., "Self-regulation learning among Taiwanese students: A longitudinal analysis of the TEPS database," Jiaoyu Kexue Yanjiu Qikan, vol. 56, no. 3, pp. 151-79, 2011.

[18] Karlen Y., "Differences in students' metacognitive strategy knowledge, motivation, and strategy use: A typology of self-regulated learners," The Journal of Educational Research, vol. 109, no, 3, pp. 253-65, 2016.

[19] Jaleel S., "A study on the metacognitive awareness of secondary school students," Universal Journal of Educational Research, vol. 4, no. 1, pp. 165-72, 2016.

[20] Ellis AK, Denton DW, and Bond JB., "An analysis of research on metacognitive teaching strategies," ProcediaSocial and Behavioral Sciences, vol. 116, no. 21, pp. 4015-24, 2014.

[21] Rahimi M. and Katal M., "Metacognitive strategies awareness and success in learning English as a foreign language: an overview," Procedia-Social and Behavioral Sciences, vol. 1, no. 31, pp. 73-81, 2012.

A quick study on SRL profiles of online learning participants during the anticipation of ... (Dwi Sulisworo) 
[22] Hee OC, Ping LL, Rizal AM, Kowang TO, and Fei GC., "Exploring lifelong learning outcomes among adult learners via goal orientation and information literacy self-efficacy," International Journal of Evaluation and Research in Education, vol. 8, no. 4, pp. 616-623, 2019.

[23] Kuo YC, Walker AE, Schroder KE, and Belland BR., "Interaction, Internet self-efficacy, and self-regulated learning as predictors of student satisfaction in online education courses," The Internet and Higher Education, vol. 1, no. 20, pp. 35-50, 2014.

[24] Aesaert K, Voogt J, Kuiper E, and van Braak J., "Accuracy and bias of ICT self-efficacy: An empirical study into students' over-and underestimation of their ICT competences," Computers in Human Behavior, vol. 75, pp. 92-102, Oct 2017.

[25] de Fátima Goulão M, Menedez RC., "Learner autonomy and self-regulation in eLearning," Procedia-Social and Behavioral Sciences, vol. 174, pp. 1900-7, Feb 2015.

[26] Zhu Y, Au W, and Yates G., "University students' self-control and self-regulated learning in a blended course," The Internet and higher education, vol. 30, pp. 54-62, Jul 2016.

[27] Matzat U. and Vrieling EM., "Self-regulated learning and social media-a 'natural alliance'? Evidence on students' self-regulation of learning, social media use, and student-teacher relationship," Learning, Media and Technology, vol. 41, no. 1, pp. 73-99, 2016.

[28] Cho MH. and Cho Y., "Self-regulation in three types of online interaction: a scale development" Distance Education, vol. 38, no. 1, pp. 70-83, 2017.

[29] Tsai CW., "How much can computers and internet help?: A long-term study of web-mediated problem-based learning and self-regulated learning," International Journal of Technology and Human Interaction (IJTHI), IGI Global, vol. 7, no. 1, pp. 67-81, 2011.

[30] Salehi A., "Teacher and student interactions and characteristics from critical theorists school," International Journal of Evaluation and Research in Education, vol. 8, no. 2, pp. 313-7, 2019.

[31] Perry JC, Fisher AL, Caemmerer JM, Keith TZ, and Poklar AE., "The role of social support and coping skills in promoting self-regulated learning among urban youth," Youth \& Society, vol, 50, no. 4, pp. 551-70, 2018.

[32] Wan Z, Compeau D, Haggerty N., "The effects of self-regulated learning processes on e-learning outcomes in organizational settings," Journal of Management Information Systems, vol, 29, no. 1, pp. 307-40, 2012.

[33] Zumbrunn S, Tadlock J, and Roberts ED, "Encourage Self Regulated Learning in the Classroom: A Review of the Literature," Metropolitan Educational Research Consortium, 2011.

[34] Schuitema J, Peetsma T, and van der Veen I., "Longitudinal relations between perceived autonomy and social support from teachers and students' self-regulated learning and achievement," Learning and Individual Differences, vol. 49, pp. 32-45, Jul 2016.

[35] McLoughlin C. and Lee MJ., "Personalised and self regulated learning in the Web 2.0 era: International exemplars of innovative pedagogy using social software," Australasian Journal of Educational Technology, vol. 26, no. 1, pp. 28-43, 2010.

[36] Järvelä S. and Järvenoja H., "Socially constructed self-regulated learning and motivation regulation in collaborative learning groups," Teachers College Record, vol. 113, no. 2, pp. 350-74, 2011.

[37] Muilenburg LY. and Berge ZL., "Student barriers to online learning: A factor analytic study," Distance education, vol. 26, no. 1, pp. 29-48, 2005.

[38] Vayre E. and Vonthron AM., "Psychological engagement of students in distance and online learning: Effects of self-efficacy and psychosocial processes," Journal of Educational Computing Research, vol. 55, no. 2, pp. 197-218, 2017.

[39] Panadero E., "A review of self-regulated learning: Six models and four directions for research," Frontiers in psychology, vol. 8, no. 422, pp. 1-28, 2017.

[40] Evertson CM. and Weinstein CS, Handbook of classroom management: Research, practice, and contemporary issues. Routledge, 2013.

[41] Barnard L, Lan WY, To YM, Paton VO, and Lai SL., "Measuring self-regulation in online and blended learning environments," The Internet and Higher Education, vol. 12, no. 1, pp. 1-6, 2009. 